\title{
The Stratton Commission- ITS HISTORY AND ITS LEGACY
}

By John. A. Knauss

$\mathrm{T}$ HE FOLLOWING REPORT is based on a talk given at a policy forum on Capitol Hill in Washington on January 25, 1990. The forum was sponsored by the Center for Ocean Law and Policy of the University of Virginia Law School.

Having served on the Stratton Commission and now holding the job as Administrator of the agency created out of its recommendations, I may have a unique point of view on its role. I do know that taking the time to review the folklore that has grown up around the Stratton Commission, and comparing that with my own recollections, was an enjoyable exercise. It was, however, more than a pleasant nostalgic recollection; it was also an opportunity to realize the dynamic qualities of the public policy process by which we brought into being a national program in marine science that is poised today to help us understand the environmental problems we face as we enter the twenty-first century.

The Public Law that eventually launched the National Oceanic and Atmospheric Administration (NOAA) was called the Marine Resources and Development Act of 1966 (P.L. 89-454). The brief description that heads the full text of printed legislation reads "An Act to provide for a comprehensive, long-range, and coordinated national program in marine science, ... to establish a National Council on Marine Resources and Engineering,... a Commission on Marine Sciences, Engineering, and Resources,... and for other purposes." PL 89-454 called for three results: the establishment of a national program in marine science, a Cabinet-level marine council, chaired by the Vice President of the United States, and the establishment of the Stratton Commission. It also began a gestational process of some four years that led, in April of 1970, to the formation of NOAA. The origins of the Stratton Commission, however, go back even further, to a series of reports issued in 1959 by the National Academy of Sciences Committee on Oceanography (NASCO). NASCO in turn was a result of a letter written in 1956 by the Chief of Naval Research to the National Academy, proposing such a committee.

John A. Knauss, Administrator of the National Oceanic and Atmospheric Administration (NOAA), Department of Commerce, 14th \& Constitution, N.W., Washington, D.C. 20230.
My guess is that Roger Revelle, Director of Scripps, Columbus Iselin, Director of Woods Hole, and Maurice Ewing, Director of Lamont (there was no Doherty in 1956) may have been silent partners in the drafting of the letter, given the close relationship they had at that time with the Office of Naval Research. NASCO was an advisory committee in a city where advisory committees are stock in trade. Reports are the lifeblood of advisory committees. Some are thoughtful; some are insightful; most hit the streets of Washington and disappear (I have been party to my share of the latter). A few, for reasons not always obvious, even in hindsight, strike a responsive chord and take on a life of their own. NASCO's twelve brief reports were such an exception.

Part of their success may have come from the fact that NASCO did a good job of marketing them. Copies went to key Congressional staffers and were brought to the attention of senior Members. Lobbying led to hearings on the state of oceanography and the importance of ocean resources. But it would be a mistake to minimize the fact that 1959 was a year marked by new enthusiasm for science in American society. The Soviet Union had launched Sputnik, shocking the nation into a new awareness of the need to make scientific inquiry a national priority.

Congress surged ahead with projects that promoted ocean science. A few agencies prospered. The Coast and Geodetic Survey got some ships, and monies flowed to the Office of Naval Research and the National Science Foundation. While the Executive Branch's enthusiasm was less pronounced, individuals like Bob Able succeeded in establishing informal networks among ocean science experts within the bureaucracy. Bob's group became in time the Intergovernmental Committee on Oceanography, marked more by its chutzpah than by its formal authority.

The Senate, led especially by Senator Magnuson, took the position that ocean programs needed a more coordinated approach. His solution was a high-level Council made up of key Cabinet members and chaired by the Vice President. On the other side of Capitol Hill, the House Merchant Marine and Fisheries Committee believed a more radical solution was required but were unable to agree on

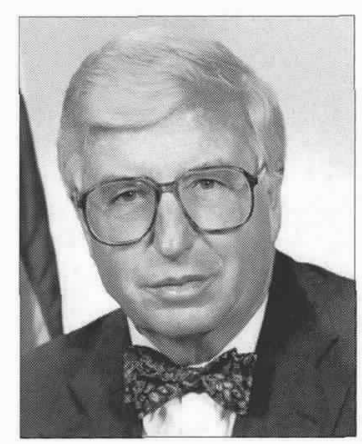

John A. Knauss 


\section{The choice of Jay}

Stratton as chairman

was, by any standard,

a stroke of genius. commission to review the situation and come forward with an organization proposal. Clearly consensus was lacking, and action was postponed.

The status quo held for several years, with discussions ongoing. Finally, in 1966, the House and Senate approaches were fused into a single bill. The Senate got its National Council on Marine Resources and Engineering Development and the House got its Commission of Marine Sciences, Engineering and Resources.

Ultimately it was the House philosophy that prevailed; the compromise called for a Commission to review the present state and future needs of marine affairs, including oceanography, marine resources, ocean engineering, education and technical training. Based on its review and analysis, the Commission would issue a report recommending a government organization plan. The Senate's Marine Council was to go out of business 120 days after the Commissions report was issued unless the Commission recommended that it continue.

The Council, chaired by Vice President Humphrey and wielding considerable influence as a result of his energy, employed Ed Wenk as executive secretary. His book, The Politics of the Ocean, documents this fertile period in the history of government marine affairs. It has all the flaws as well as the advantages of a history written by a participant, rather than a professional historian. It makes interesting reading. Vice President Humphrey also had the honor of swearing in the membership of the Commission on Marine Sciences, Engineering and Resources-the Stratton Commission-so called because its chairman was Julius Stratton, former President of Massachusetts Institute of Technology and Chairman of the Board of the Ford Foundation. The Commission had fifteen members, many of whom had little involvement with ocean issues until their appointment. Among the members were: Carl Auerbach. a professor of constitutional law and former director of Vice President Humphrey"s campaign for mayor of Minneapolis some years earlier; George Reedy, who had been President Johnson's press secretary; Leon Jaworski, then a well-known Houston lawyer and friend of President Johnson who later become President of the American Bar Association and the independent prosecutor in the Watergate investigation; Jacob Blaustein, founder and President of Standard Oil of Indiana; from the ocean engineering and science community: Tap Pryor. President of the Oceanic Foundation in Hawaii; Jim Crutchfield, a resource economist whose work had included a number of publications on fisheries issues; and John Perry, a dedicated amateur whose publishing company had spun off a subsidiary that manufactured small submarines; from government service: Charles Baird, Under Secretary of the Navy; Frank DiLuzio. Assistant Secretary of the Interior for Water Pollution Control: and Bob White, Administrator of the Department of Commerce's Environmental Sci- ence Services Administration. which included, at that time, the Weather Bureau and the U.S. Coast and Geodetic Survey. None of the movers and shakers of the original set of NASCO reports was appointed. Men like Roger Revelle, Harrison Brown or Athelstan Spilhaus were not tapped. Nor were members of the senior oceanography establishment such as Wib Chapman. John Isaacs or Paul Fye. I've often wondered what they thought of my appointment; after all. I had only been a member of NASCO for about a year.

The Stratton Commission was a success from its very beginning. The choice of Jay Stratton as chairman was. by any standard, a stroke of genius. He immediately gathered an excellent staff, and, perhaps even more important, he had the knack of making each member of the Commission feel responsible for the results of our communal assignment. From my personal point of view, this was a heady experience. I was in awe of the contacts and panache of my colleagues, but I felt some concern for their lack of ocean expertise, despite their otherwise excellent credentials.

One morning, during a coffee break, Jay Stratton took me aside. I recall he said, "If we are going to succeed, I need your help desperately. You are the only real ocean expert we have." I was both flattered and flabbergasted. In the face of the knowledge that the entire success or failure of the Commission rested on my shoulders, I had no choice but to commit my every waking comment to the effort. It was years later that I realized that at each of the coffee breaks in those early days of our work, Jay had taken each of my fellow commissioners aside and given them much the same pitch. He saw clearly that each of us had an important role to play, each had a kind of expertise needed for the tasks at hand, and each of us needed to believe that his contribution was essential for success.

The result of his teambuilding was that everyone tapped into the wider resources available to them beyond the scope of the Commission itself. Carl Auerbach talked to experts in the field of law and brought to the table a proposal for deep-sea bed mining and offshore oil drilling boundaries not unlike the original U.S. position at the Law of the Sea Conference some six years later. If we had been able to hold to the position he outlined, chances are excellent that we would have a ratified convention by now. Jim Crutchfield, as another example, went beyond his expertise in fishery resources to pull together a summary of the current state of marine resources that was comprehensive to say the least. The staff Jay Stratton had assembled came largely from the federal bureaucracy. The men and women who came to the effort brought with them the conviction that our work would color their methods of doing business for years to come, and their commitment matched the challenge. Bob Dinsmore, my chief staff assistant in the effort to define coastal 
zone management, was the youngest captain in the Coast Guard. He helped form the nucleus of Senator Holling's Coastal Zone Management Act of 1972.

The Commission gathered for monthly meetings, with panels on international issues, marine resources, environmental monitoring. basic science. marine engineering and technology among the list of topics. The original intention had been to use the panel reports as the framework for the Commission's report, adding organizational recommendations hashed out in the full Commission hearings. But such was not to be the case. The technology recommendations. in particular, were problematic. They carried a price too high for many Commission members to support. The compromise was that each panel's report would be published, but that the Commission's final report would capture only those recommendations on which all members could agree.

Once again Jay Stratton's skill was evident. He postponed formal discussion of organization until nearly the end of our deliberations, choosing the agehonored tradition of setting form after function had been defined. In the end, we had little difficulty in agreeing on a proposal for an independent National Oceanic and Atmospheric Administration. The fine tuning of that final report was a two-day effort. A committee that included Bob White, Carl Auerbach. Jim Crutchfield and me worked through the draft material, line by line and word by word. As each section was completed, we sent it upstairs to the full membership for review and approval. Several sections, I regret to say, came back for further revision. Twenty years later. I am still amazed at the fact that the Stratton Commission report managed to bring about fundamental change. Certainly the odds were not in its favor. After all, our report. "Our Nation and the Sea," was delivered to President Johnson during his last month in office, on January 9, 1969. He had appointed us, and his Vice President had been chairman and cheerleader for the Marine Council. But in the waning days of his administration. the President's support was secondary in importance to the attitudes of the Nixon Administration, during whose watch the changes would have to be adopted.

Some observers have compared the events of those months with the old movie adventure series "The Perils of Pauline." There is some wisdom in that view. But Congress responded with enthusiasm to the recommendations in the Commission's report, and pressure built for their ultimate adoption. Difficulties abounded, however. President Johnson's decision not to run for reelection was based largely on the build-up of the war in Vietnam. The war may well have been a factor in Vice President Humphrey's defeat in the election in the fall of 1968 . Furthermore, 1968 had been the year in which Robert Kennedy and Martin Luther King, Jr., had died, and American cities had erupted in race riots throughout that summer. In addition, neither President Nixon or Vice President Agnew evinced much enthusiasm for the work of the Commission.

Even so, in what some have considered record time. NOAA was created by Reorganization Plan 4 , signed by President Nixon on October 3, 1970. The Commission had recommended independent agency status for NOAA , while others had urged a partnership with the Coast Guard, But most of the features of the Commission's report were honored, along with a number of additional fillips. And over the longer haul, other recommendations that were not immediately picked up were put in place. Congress established the National Advisory Council on the Ocean and Atmosphere (NACOA) and the Coastal Zone Management Act was passed. The University National Oceanographic Laboratory System (UNOLS) was formed as an alternative to the National Laboratories that we had proposed, and the Estuarine Reserves and National Sanctuaries proposals were an imaginative response to our plan for areas to be set aside for sanctuaries and for study. But the story is not complete without some reference to some of our shortcomings. The area in which we had the least success was technology. The Stratton Commission recommended that NOAA take responsibility for supporting fundamental ocean engineering technology and a series of national priority projects such as continental shelf laboratories and deep submersible systems. Neither Congress nor the Executive Branch have taken the lead on those aspects of advancing our nation's undersea technology, despite industry support for a "wet NASA."

"Our Nation and the Sea" included 121 recommendations. No doubt someone has gone through the report, tallying up our success rate, although I have not seen such a study. Many of our recommendations were so clearly in the mainstream that they might have been implemented whether or not the Stratton Commission had been impaneled. But at the least our work hastened the adoption of programs and projects that were already in the intellectual pipeline. Congress and the Administration may have amended, modified or improved on the ideas raised in our report, but there has been a great deal of satisfaction among the Commission members over the years for the fact that our report had a profound effect on marine policies across the nation. I am certainly grateful, some twenty years later, to have been part of the process. $\square$
Twenty years later,

I am still amazed at the

fact that the Stratton

Commission report

managed to bring

about fundamental

change. 